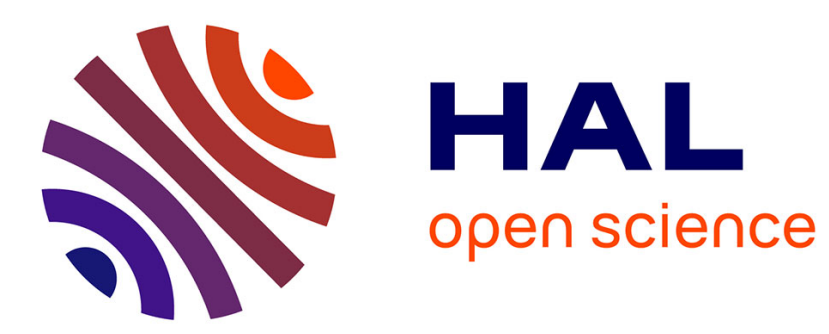

\title{
Defining Groundwater Remediation Objectives with Cost-benefit Analysis: Does It Work?
}

\author{
Jean-Daniel Rinaudo, Stéphanie Aulong
}

\section{To cite this version:}

Jean-Daniel Rinaudo, Stéphanie Aulong. Defining Groundwater Remediation Objectives with Cost-benefit Analysis: Does It Work?. Water Resources Management, 2014, 28 (1), pp.261-278. 10.1007/s11269-013-0483-0 . hal-00934930

\section{HAL Id: hal-00934930 \\ https://hal.science/hal-00934930}

Submitted on 22 Jan 2014

HAL is a multi-disciplinary open access archive for the deposit and dissemination of scientific research documents, whether they are published or not. The documents may come from teaching and research institutions in France or abroad, or from public or private research centers.
L'archive ouverte pluridisciplinaire HAL, est destinée au dépôt et à la diffusion de documents scientifiques de niveau recherche, publiés ou non, émanant des établissements d'enseignement et de recherche français ou étrangers, des laboratoires publics ou privés. 

benefit analysis: does it work?

BRGM (French Geological Survey) 1034 rue de Pinville, 34000 Montpellier, France.

*Corresponding author (E-mail: jd.rinaudo@brgm.fr)

Abstract

The use of cost-benefit analysis (CBA) is increasingly advocated as a tool for supporting water planning decisions, in particular at the local (site) level. This paper questions whether CBA is relevant for evaluating groundwater management options at the scale of large regional aquifers. It highlights the difficulties related to estimating the cost of groundwater protection and remediation measures at the regional (water body) level. It also identifies methodological challenges in estimating the economic value of the benefits of groundwater protection. The paper is based on an original case study carried out on the upper Rhine valley aquifer in eastern France. The methodology deployed combines engineering approaches to assess the cost of remediation and economic methods (contingent valuation) to estimate the benefits associated with groundwater improvement.

\section{Keywords}

Cost-benefit analysis; groundwater remediation; contingent valuation survey; volatile organic compounds (VOC); willingness to pay. 


\section{INTRODUCTION}

29 Following the promulgation of the Water Framework Directive (2000/60/EC), the European

Commission prepared and published a daughter directive (2006/118/EC) which focuses on

groundwater-specific issues. One of the main purposes of this daughter directive was to establish a general framework and procedures for specifying the quality levels which should be achieved in various hydro-geological contexts (Quevauviler, 2008). The Directive recognises that groundwater quality objectives should be set considering the local geological context and natural background concentrations and that no uniform standards should apply uniformly across Europe.. The definition of groundwater quality objectives may also be based on an economic assessment of the costs and benefits of reaching different quality levels (Brouwer, 2008). This flexible policy approach leads to a new demand for methodologies and reference case studies which can be used to construct a practical Cost-Benefit Analysis (CBA) approach for application in groundwater protection programs. This paper employs a case study approach to discuss some of the key related methodological issues.

Implementing cost-benefit analyses of alternative groundwater protection or restoration scenarios is no trivial task. For historical reasons, CBA has been more widely used in the US than in European countries (Pearce, 1998) in particular for promoting efficient use of scarce financial resources allocated to soil and groundwater decontamination (Kiel \& Zabel, 2001). Concerning industrial contamination, CBA has mostly been applied at the site (local) level (Hardisty \& Özdemiroglu, 2005; Rinaudo \& Loubier, 2005). CBA has also been used to assess agricultural pollution control programs, with one study considering a range of pollution levels (Yada \& Wall, 1998). However, American studies have generally focused on situations where the benefits of groundwater protection and/or decontamination are related to direct groundwater use. Benefits are often considered as avoided costs - such costs consisting of health-damage costs (Sharefkin, Shechter \& Kneese, 1984) or the cost of averting behaviours 
(Abdalla, 1994, Yadav \& Wall, 199). Even contingent valuation studies mainly consider use benefits (for a review see Hardisty \& Özdemiroglu, 2005, Poe, Boyle \& Bergstrom, 2001).

This is a quite different situation from that of Europe, where the population is almost entirely supplied by public water systems. The only direct link that exists between groundwater quality and households' wellbeing is the price they pay for the drinking-water supply (increasing water treatment cost in case of pollution) and the possible impact of groundwater deterioration on groundwater-dependent ecosystems. Clearly, only a tiny minority of households depending on private wells would be directly concerned by health risks due to groundwater pollution or by the need to invest in private treatment. A consequence is that, in the European context, groundwater valuation studies should focus more on the ecological benefits generated by action programs, and less on direct use benefits alone. This is also required by the European Water Framework Directive.

The first methodological issue investigated in this paper is how to assess the economic value of ecological benefits associated with groundwater protection or remediation. The Contingent Valuation (CV) method can theoretically be used to assess such ecological benefits, if respondents are provided with precise information on the impact that the action scenario in question would have on a groundwater-dependent ecosystem (Carson et al, 2001; Brouwer, 2008). However, a review of the literature shows that few studies have done this. Following the seminal study by Edwards (Edwards, 1988), a significant literature has addressed how to assess the economic value of groundwater protection benefits. In the USA, following the recommendation of the Water Resources Council, most of the studies have used the contingent valuation (CV) method. In their 2001 paper, Poe et al. identify 19 groundwater valuation studies using CV (Poe, Boyle \& Bergstrom, 2001). However, Poe notes that many of these studies are valuing the improvement of groundwater quality when used by households for their own water supply. An extreme example is the study of Jordan \& 
Elnagheeb (1993) who assess the willingness of households to pay for treating groundwater before use. Fewer studies were designed to assess both use and non-use benefits, considering the impacts on groundwater-dependent ecosystems (Lazo, Schulze et al. 1992) and the interactions between groundwater and ecosystem-protection benefits (Randal, DeZoysa \& Yu, 2001). In Europe, published studies are still scarce and they do not really address the issue of the valuation of the ecological benefits of groundwater protection and remediation (Press \& Söderqvist, 1998, Rozan, Stenger \& Willinger, 1997, Stenger \& Willinger, 1998, Tentes \& Damigos, 2012).

The second methodological issue investigated in this paper relates to the evaluation of benefits associated with various groundwater-quality levels. Most of the studies found in the literature use the contingent valuation method to assess a population's willingness to pay (WTP) for achieving a specific predefined groundwater-quality target. This paper presents an attempt to fill this gap by means of a case study in which costs and benefits are estimated for several groundwater-quality levels. The originality of the approach lies in the combination of economic and engineering approaches: these are too often kept separate in the economic literature which focuses solely on benefits. The approach is implemented in a case study located in eastern France where the groundwater is polluted with Volatile Organic Compounds (VOC), a group of substances widely used (mainly as solvents) in industry and frequently detected in groundwater.

This paper is organised as follows. The next section describes the case study area and the methodology used to assess the cost of remediation and the benefits generated. Results are presented in the third section, and the paper concludes with a discussion of problems related to the use of contingent valuation in groundwater CBA.

\section{CASE STUDY AND METHODOLOGY}

\subsection{Presentation of the case study}


103 The upper Rhine valley alluvial aquifer is located between Germany and France, and covers

1044200 square kilometres. With a reserve of approximately $45 \mathrm{~km}^{3}$ of water - approximately

105 half of the volume of Lake Geneva - this aquifer is one of the largest fresh water reserves in

106 Europe. Groundwater from the Rhine alluvial valley supplies $75 \%$ of the drinking water needs

107 and about half of the industrial water needs of the region. More than three million inhabitants

108 of Alsace (France) and Baden-Württemberg (Germany) directly depend on this resource for

109 their water supply. Although usable for drinking purposes without prior treatment in most 110 locations, groundwater has been progressively affected by both diffuse and point-source

111 pollution since the 1970s. Four major pollutions sources threaten this aquifer: nitrates,

112 pesticides, chlorides, and VOC. High VOC concentrations have been detected downstream of

113 several industrial areas. The most frequently observed molecules are trichloroethylene (TCE),

114 tetrachloroethylene (PCE) and 111 trichloroethane (111 TRI). In a groundwater-quality 115 measurement campaign carried out in 1996-97, at least one of the three substances listed

116 above was detected in $38 \%$ of the 423 French and 533 German groundwater samples. The

117 measured concentrations were less than $0.2 \mu \mathrm{g} / \mathrm{l}$ in $70 \%$ of the contaminated samples. Values

118 ranging between 0.2 and $10 \mu \mathrm{g} / \mathrm{l}$ are reported in $25 \%$ of the samples. Only $6 \%$ of the samples

119 show concentrations higher than $10 \mu \mathrm{g} / \mathrm{l}$, which is the maximum value for drinking water use 120 according to the EU standard.

\subsection{Programme of groundwater-restoration measures: design and cost assessment}

123 The first part of the research consisted of developing a tool for designing and assessing the

124 cost of the programme of measures required to achieve various groundwater-quality 125 objectives. The major steps involved in the development of that tool are depicted in figure 1.

126 The tool incorporates several databases and Visual Basic queries developed using Microsoft

127 Access ${ }^{\circledR}$. Given a groundwater-quality objective (maximum concentration) specified by the 
user, the tool successively performs the following steps:

(1) It first identifies all groundwater areas where the observed VOC concentration exceeds the targeted threshold value; this is done by using the regional groundwater-quality database, which comprises information for 423 monitoring points; this step defines the geographical scope of the programme of measures.

(2) The tool then identifies all sites and firms (industrial companies and other) located within the area selected in Step 1 which are likely to generate a significant risk of pollution. Companies are selected using a list of 110 potentially polluting activities which was established after an extensive literature review, internet searches, and advice from industrial experts. This step also uses statistical databases which provide detailed technical and economic information on all firms at the municipal level (SIREN database) and on historical contaminated sites (Basias and Basol databases).

(3) The third step consists of identifying the prevention and remediation measures that need to be implemented for all selected firms and historical contaminated sites. This is based on a matrix specifying a list of measures for each of the 110 economic activities considered (Table 1). This matrix was also established based on literature review, internet search, and expert advice.

(4) Finally, the tool assesses the total cost of the programme of measures defined in Step 3. This is based on a cost matrix which specifies the investment and recurring costs for all measures. An annual cost is estimated considering the technical lifespan of each measure, applying a $4 \%$ discount rate. More details on the types of measures and on cost estimation are provided in Appendix 1. 
Major point-source pollution

\begin{tabular}{|c|c|c|c|c|c|}
\hline & & & & & \\
\hline Origin & $\begin{array}{l}\text { Historical } \\
\text { contaminated } \\
\text { sites }\end{array}$ & Active industrial sites & $\begin{array}{l}\text { Accidents } \\
\text { (transportation, } \\
\text { storage) }\end{array}$ & $\begin{array}{l}\text { Households \& } \\
\text { small industries }\end{array}$ & $\begin{array}{l}\text { Atmospheric } \\
\text { contamination }\end{array}$ \\
\hline $\begin{array}{l}\text { Type of } \\
\text { measures }\end{array}$ & $\begin{array}{l}\text { Remediation } \\
\text { measures: soil } \\
\text { decontamination, } \\
\text { pollution plume } \\
\text { control } \\
\text { (hydraulic } \\
\text { barriers) }\end{array}$ & $\begin{array}{l}\text { Remediation measures: } \\
\text { soil treatment, plume } \\
\text { control. } \\
\text { Preventive measures: } \\
\text { effluent treatment, } \\
\text { monitored storage } \\
\text { tanks, leach water } \\
\text { collection, } \\
\text { technological changes, } \\
\text { recycling of solvents, }\end{array}$ & $\begin{array}{l}\text { Remediation } \\
\text { measures: } \\
\text { pollution } \\
\text { removal. } \\
\text { Preventive } \\
\text { measures: } \\
\text { specific waste } \\
\text { collection, ban } \\
\text { on VOC in } \\
\text { residential uses, } \\
\text { additional } \\
\text { treatment in } \\
\text { sewage plants. }\end{array}$ & $\begin{array}{l}\text { Remediation } \\
\text { measures: soil } \\
\text { treatment, } \\
\text { plume control. } \\
\text { Preventive } \\
\text { measures: } \\
\text { transport and } \\
\text { delivery } \\
\text { precautions, } \\
\text { monitoring of } \\
\text { roadside ditches } \\
\text { and waters. }\end{array}$ & $\begin{array}{l}\text { Preventive } \\
\text { measures: } \\
\text { limiting } \\
\text { atmospheric } \\
\text { VOC } \\
\text { emissions } \\
\text { (covered by } \\
\text { existing } \\
\text { regulations) }\end{array}$ \\
\hline
\end{tabular}

point-source pollution

pollution

(6) Table 1: Overview of measures considered for remediation of VOC pollution.

environmental objectives

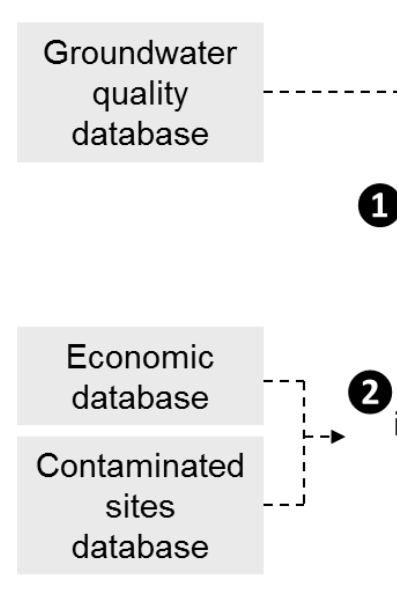

(threshold value)

Dispersed Diffuse

\section{Figure 1: Main steps of the methodology used for designing the programme of measures.}




\subsection{Assessment of environmental benefits}

\section{$159 \quad$ 2.3.1. Contingent valuation survey}

160 The second part of the research consisted of assessing the benefits associated with

161 groundwater protection. The benefits were estimated by eliciting the population's willingness

162 to pay (WTP) for the two levels of groundwater protection. A contingent valuation survey was

163 carried out between March and July 2006 using a postal survey. The mail survey method was

164 chosen to ensure that respondents would have sufficient time to get to know an unfamiliar

165 subject, and think about preferences. Following a careful pre-test of the questionnaire in 140

166 face-to-face interviews, the questionnaire was mailed out to 5,000 households selected in rural

167 localities $(2,000)$, urban areas $(2,000)$ and in municipalities located outside the aquifer which

168 used other water resources $(1,000)$. The survey response rate was $13 \%$, equally distributed

169 between urban and rural municipalities $(49-51 \%)$ and with respectively 79 and $21 \%$ of

170 respondents located above and outside the aquifer.

171 One of the main specific characteristics of the survey consisted of asking respondents to

172 consider and value two scenarios (for a similar approach focusing on surface water, see

173 Lienhoop \& Messner, 2009). The first scenario, assumes that groundwater-remediation

174 measures are implemented only in areas where pollutant concentrations exceed drinking-

175 water standards. The main expected benefits consist of avoiding costly water treatment for

176 present and future generations. Respondents are informed that traces of contamination remain

177 in parts of the aquifer with possible impacts on groundwater-dependent aquatic ecosystems

178 (wetlands, rivers). Drinking water supply may also contain traces of contaminants but at

179 concentration levels below European standards (no health risk). This information is supported

180 in the questionnaire by a groundwater-quality map. The second scenario assumes that

181 groundwater-remediation measures are implemented in all areas where traces of VOC are

182 detected. The benefits of this scenario derive from restoring pristine water quality. This also 
184 groundwater-dependent ecosystems are no longer threatened by residual groundwater 185 pollution; and that future generations inherit a much improved natural heritage. The main 186 features of the two scenarios which were presented to respondents are summarised in Table 2.

\begin{tabular}{|c|c|c|}
\hline & Scenario 1 & Scenario 2 \\
\hline Objective & Restoring groundwater potability & $\begin{array}{l}\text { Restoring natural groundwater quality (no } \\
\text { traces of solvents in the long term) }\end{array}$ \\
\hline PoM timing & 10 years & 10 years \\
\hline \multirow[t]{2}{*}{$\begin{array}{l}\text { Actions } \\
\text { implemented } \\
\text { as part of the } \\
\text { scenario }\end{array}$} & $\begin{array}{l}\text { - Remediation measures implemented in } \\
\text { historical contaminated sites located in } \\
\text { areas where CS exceeds drinking water } \\
\text { threshold value }\end{array}$ & $\begin{array}{l}\text { - Remediation measures implemented in } \\
\text { historical contaminated sites located in } \\
\text { areas where traces of solvents are detected }\end{array}$ \\
\hline & $\begin{array}{l}\text { - Preventive measures applied (through } \\
\text { regulation) in all enterprises using } \\
\text { chlorinated solvents and located in areas } \\
\text { where concentrations in solvents exceed } \\
\text { drinking water threshold. }\end{array}$ & $\begin{array}{l}\text { - Preventive measures applied (through } \\
\text { regulation) in all enterprises using } \\
\text { chlorinated solvents and located in areas } \\
\text { where traces of solvents have been detected }\end{array}$ \\
\hline \multirow[t]{3}{*}{$\begin{array}{l}\text { Expected } \\
\text { benefits }\end{array}$} & $\begin{array}{l}\text { - Drinking water quality level restored } \\
\text { within } 10 \text { years but traces of CS remain in } \\
\text { the aquifer, with risk of impacts on }\end{array}$ & $\begin{array}{l}\text { - Natural quality restored, traces of CS } \\
\text { disappear within } 50 \text { years: natural } \\
\text { attenuation contributes. }\end{array}$ \\
\hline & $\begin{array}{l}\text { ecosystems. } \\
\text { - Reduction in future drinking-water } \\
\text { treatment cost. }\end{array}$ & $\begin{array}{c}\text { - Environmental benefits for ecosystems and } \\
\text { water-related species, absence of risk for } \\
\text { humans using groundwater. }\end{array}$ \\
\hline & & - Heritage benefits (for future generations). \\
\hline
\end{tabular}

Table 2: Summary of groundwater scenario presented to respondents in the survey questionnaire.

\subsubsection{Contingent valuation questionnaire}

190 The questionnaire is organised as follows. It starts with a brief description of the upper Rhine

191 valley aquifer, accompanied by a map intended to help respondents determine whether the

192 locality they live in is located above the aquifer or not. This is followed by a set of questions

193 related to the respondent's use of the aquifer (private well, drinks tap water or not, practice of

194 leisure activities related to water). It then focuses on respondent's perception and knowledge

195 of groundwater. Respondents are then informed about the groundwater contamination

196 problem and its expected future evolution. The four major pollution sources (nitrates,

197 pesticides, chlorides from the mining industry, and chlorinated solvents) are presented. We 
explain that whereas the problems of nitrates, pesticides, and chloride should be solved by

1992015 by measures already implemented, pollution by chlorinated solvents will remain as an 200 obstacle to good groundwater quality. The extent of today's pollution by chlorinated solvents

201 is depicted on a map which shows in red the locations where solvents have been found in 202 concentrations exceeding drinking-water thresholds, and in yellow where traces that do not 203 exceed the drinking water threshold have been found. The text briefly identifies the origins of 204 the contamination and outlines the future pollution trends if no remediation and preventive measures are undertaken to control the pollution. The description of the two action scenarios follows. Respondents are then asked how realistic the scenarios are and about their willingness to pay to obtain the related benefits. Follow-up questions are used to understand 208 their motivations to pay (or to refuse payment). The questionnaire ends by collecting the 209 respondent's socio-economic characteristics.

210 The two scenarios are presented successively to respondents ${ }^{1}$. Households are asked how 211 much they would be willing to pay over ten years ${ }^{2}$ on top of their water bill . A payment card 212 is offered to the respondents to elicit their WTP. The card includes thirty five amounts, with a 213 minimum of $€ 2$ (besides a zero bid which is also allowed) and a maximum of $€ 500$ (value 214 chosen after the questionnaire was tested in face-to-face interviews, see below). ${ }^{3}$

\footnotetext{
${ }^{1} \mathrm{~A}$ careful pre-test of the questionnaire showed that the order in which the two scenarios were presented to respondents had no effect on stated WTP. In the postal survey, the two scenarios were presented in the same order in all questionnaires.

${ }^{2}$ Respondents are requested to state the amount they would be willing to pay over the ten years corresponding to the implementation of the program of measures. WTP is thus expressed in $€ /$ household/year over 10 years.

${ }^{3}$ For a discussion of the pro and cons of the payment card approach versus the dichotomous choice experiment approach, see Ryan et al, 2004.
} 


\section{RESULTS}

\section{8 \\ 3.1. Cost of groundwater restoration}

219 In the first scenario, we assume that specific protection and remediation measures are applied

to sites and firms located in areas where groundwater exhibits VOC concentrations exceeding

221 the drinking-water quality threshold. No specific action is undertaken in other areas where the

222 presence of VOC is detected but does not exceed the drinking-water threshold. The second

223 scenario aims at suppressing all sources of VOC contamination. This scenario assumes that

224 the same technical measures are applied to all sites and firms located in areas where traces of

225 VOC have been detected, including locations where pollution does not exceed drinking-water

226 standards. The programmes of measures corresponding to the two scenarios are assessed

227 using the computer tool described in the previous section.

228 As shown in Table 3, the number of firms involved in the programme of actions is significantly larger for the second scenario than for the first one. The total cost, estimated at $€ 52$ million, is more than twice that of Scenario $1(€ 22 \text { million })^{4}$. One of the questions then

231 raised by policy makers is whether the benefits generated by the overall higher water quality

232 justify the additional cost of approximately $€ 30$ million.

233

\begin{tabular}{ccc}
\cline { 2 - 3 } & S1 & S2 \\
\hline Number of enterprises & 466 & 1933 \\
\hline Number of employees & 13075 & 62568 \\
\hline Turn over (million $€$ ) & 3081 & 17504 \\
\hline Added value (million $€$ ) & 734 & 3793 \\
\hline Cost of action in millions $€$ & 22 & 52 \\
(in \% of added value) & $(3 \%)$ & $(1.4 \%)$ \\
\hline
\end{tabular}

234 Table 3: Enterprises located in areas where the presence of VOC is detected and for which preventive measures

235 are implemented (Scenarios 1 and 2).

\footnotetext{
${ }^{4}$ Investment costs that will be incurred at the beginning of the period represent respectively $82 \%$ and $86 \%$ for the two scenarios. Recurring operational and maintenance cost will spread over a ten-year periods. They are converted into net present value using a $4 \%$ discount rate.
} 
237 The calculations were then repeated for several water quality objectives. In each calculation, 238 the objective was defined by a target groundwater maximum VOC concentration which 239 ranges between 0 (removal of all traces of pollutant) and the drinking-water quality standards 240 (DWQS). The results, depicted in Figure 2 below, show that the cost of the programme 241 remains relatively stable for a targeted water quality of between $50 \%$ and $100 \%$ of the 242 DWQS. The cost of the PoM increases significantly when the quality objective goes below $24340 \%$ of the DWQS. The increase which occurs around $40 \%$ is mainly due to an increase in the 244 number of historical contaminated sites involved in the programme of actions.

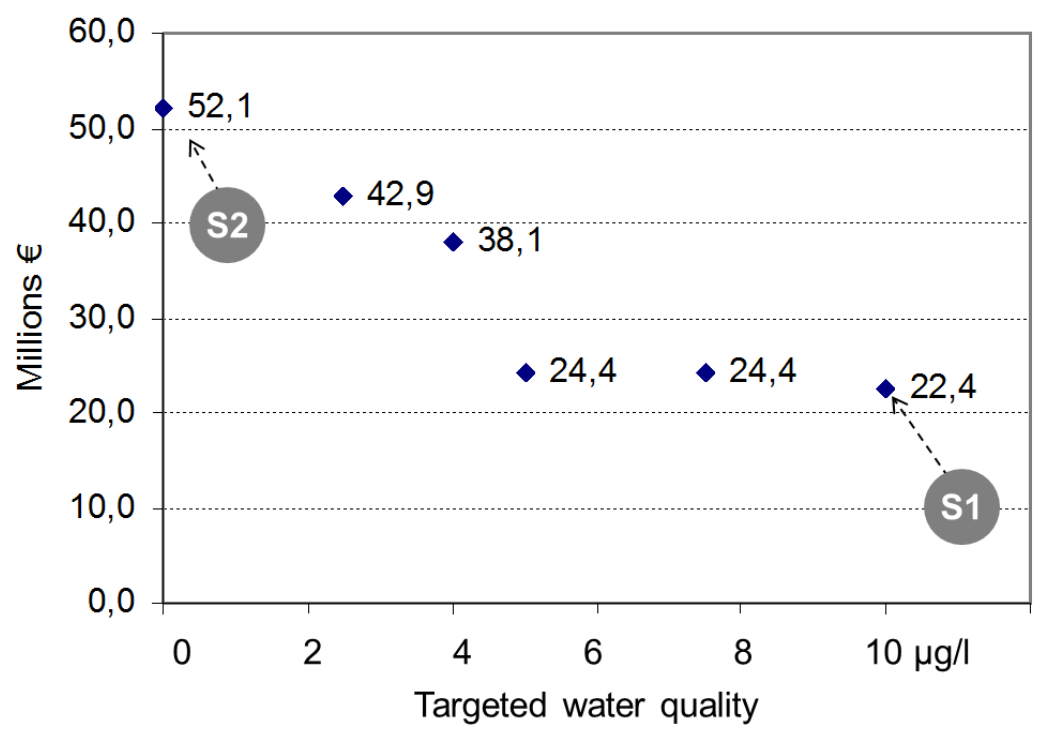

Figure 2: Evolution of the total cost as a function of the targeted quality threshold value (expressed in percentage of drinking water standards for COV).

250 These results were presented to experts from the Rhine Meuse Water Agency. They 251 considered them to be a very useful input to their planning process. They emphasized the 252 difficulties they usually face when trying to assess the cost of groundwater remediation 253 programmes covering several hundreds or thousands of pollution sources. The systematic 
254 approach implemented in this research provided useful elements for budget planning. They

255 were also very interested to learn that most of the cost was related to actions to be 256 implemented in three industrial sectors (see Table 4). Last but not least, the information 257 related to the distribution of cost per category of action (see Figure 3) was also considered to 258 be very useful when planning actions regarding the budget, and technical and human 259 resources.

260

\begin{tabular}{|c|c|c|c|c|}
\hline \multirow[b]{2}{*}{ Economic sector } & \multicolumn{2}{|c|}{ Cost of PoM $(€ 000)$} & \multicolumn{2}{|c|}{$\%$ of total cost of PoM } \\
\hline & $\mathrm{S} 1$ & $\mathrm{~S} 2$ & $\mathrm{~S} 1$ & $\mathrm{~S} 2$ \\
\hline $\begin{array}{l}\text { Activities producing or using paint and } \\
\text { varnishes }\end{array}$ & 11,056 & 13,769 & $49 \%$ & $26 \%$ \\
\hline Mechanical industry & 3,606 & 12,039 & $16 \%$ & $23 \%$ \\
\hline Contaminated sites & 2,987 & 8,308 & $13 \%$ & $16 \%$ \\
\hline Metal-coating industry & 1,891 & 5,566 & $8 \%$ & $11 \%$ \\
\hline Car and motorcycle repair workshops & 1,097 & 4,408 & $5 \%$ & $9 \%$ \\
\hline Chemical industry & 881 & 4,422 & $4 \%$ & $9 \%$ \\
\hline Printing & 378 & 1,439 & $2 \%$ & $3 \%$ \\
\hline Textile industry & 184 & 924 & $0.80 \%$ & $2 \%$ \\
\hline Manufacture of electrical /electronic products & 166 & 471 & $0.70 \%$ & $0.90 \%$ \\
\hline Industrial-cleaning industry & 60 & 396 & $0.30 \%$ & $0.80 \%$ \\
\hline Food and beverage industry & 47 & 340 & $0.20 \%$ & $0.70 \%$ \\
\hline Metal-processing and cutting industry & 46 & 60 & $0.20 \%$ & $0.10 \%$ \\
\hline Total & 22,405 & 52,147 & $100 \%$ & $100 \%$ \\
\hline
\end{tabular}

Table 4: Enterprises located in areas where the presence of VOC is detected and for which preventive measures are implemented (Scenarios 1 and 2). 


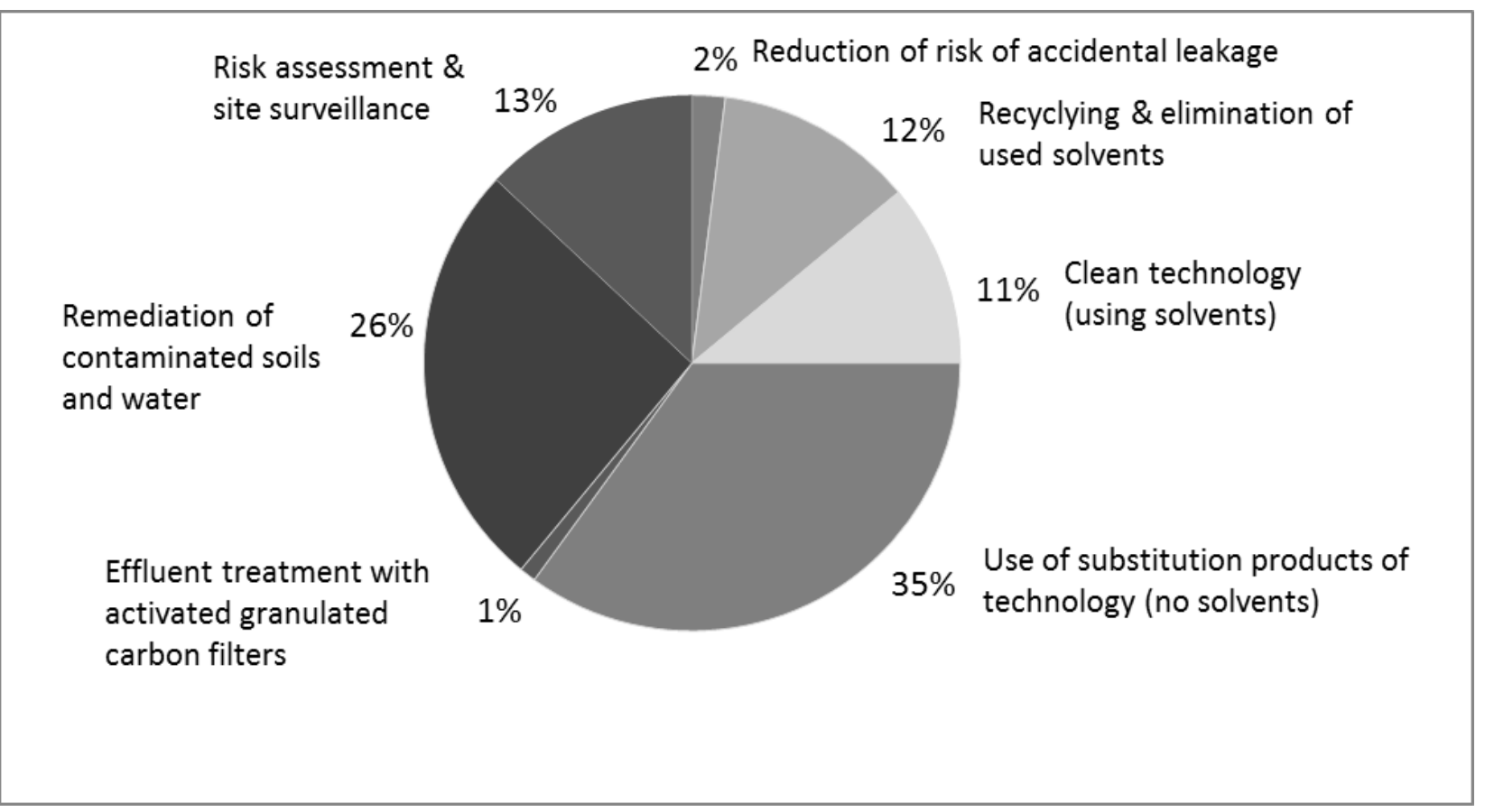

Figure 3: Distribution of the total cost per category of measures.

\subsection{Willingness to pay for groundwater protection: survey results}

268 The results of the survey highlight the fact that the population is concerned about groundwater

269 protection. Groundwater pollution is identified as the second most important environmental

270 problem after air pollution (45 and $48 \%$ respectively).

271 Sixty-two percent of respondents would agree to pay for remediating groundwater under

272 Scenario 1, which consists of restoring drinking-water quality standards in the aquifer. The

273 average stated WTP is €42/year/household (in $2006 €$ ), which is in the lower range of values

274 reported elsewhere in the world (see Bergstrom et al., 2001). It is also slightly lower (in

275 constant euros) than the WTP values estimated by Stenger et al. (1998) in the same case study

276 ten years earlier. Note that comparison of stated WTP in absolute value terms is a difficult

277 exercise, since WTP values are highly dependent on the information provided to respondents

278 (baseline scenario, information related to health impacts of pollution, etc.).

279 When asked to justify why they contribute, most respondents explain they want to preserve an 
option for potential future use of the aquifer for themselves (option value) or future 281 generations (bequest value). Other reasons presented are the personal current direct use of the aquifer via the municipal water supply system (direct use value) and the satisfaction from preserving aquatic life in groundwater dependent ecosystems for present (indirect use value) and future generations (bequest value).

Another interesting result is that $54 \%$ of respondents in our survey are willing to pay more for improving groundwater quality beyond strict compliance with drinking-water quality standards (€76/year/household on average). Information collected by the authors when testing the questionnaire in face-to-face interviews helps understanding this result. Many respondents are concerned by the presence of dangerous substances in the water they drink, even if the authorities can guarantee that drinking-water standards are met. Most of these people are 291 drinking bottled water because they do not place trust in tap water. They are therefore willing to pay to remove all traces of pollution so that they can again rely on tap water for daily use.

293 Their WTP reflects an increased use value. Other respondents indicate their willingness to pay 294 for removing environmental risks which are not related to health (potential impacts of VOC 295 on fauna and flora). Their WTP indicate a non-use value. Overall, it was not possible from our 296 survey to disentangle use and non-use values.

297 The study also reveals that the population is very sensitive to the implementation of the 298 "polluter pays" principle. Many respondents, who refused to contribute to the scenarios for 299 protest motives (see column "protest" in table 5), argued that polluters (industries) should pay, 300 not citizens. Similar attitudes have been reported in other case studies where polluters are 301 known and theoretically liable to pay for remediation costs (Tentes \& Damigos, 2012). 


\begin{tabular}{cccc}
\hline Number of & WTP $>0$ & \multicolumn{2}{c}{ WTP $=0$} \\
\cline { 2 - 4 } respondents & & Protesters & True zero \\
\hline Scenario 1 & $\mathrm{N}=381$ & $\mathrm{~N}=170$ & $\mathrm{~N}=63$ \\
& $(62 \%)$ & $(28 \%)$ & $(10 \%)$ \\
Scenario 2 & $\mathrm{N}=344$ & $\mathrm{~N}=111$ & $\mathrm{~N}=159$ \\
& $(56 \%)$ & $(18 \%)$ & $(26 \%)$ \\
\hline
\end{tabular}

Table 5: Number of respondents accepting refusing to pay for the two scenarios.

\subsection{WTP econometric analysis}

306 Econometric models were developed to investigate whether the expected relationships 307 between WTP and independent variables hold. Separate models were tested and estimated to 308 explain the stated WTP for Scenarios 1 and 2. We used both OLS regressions ${ }^{5}$ (excluding zero values) and the Tobit model (for WTP $\geq 0$ excluding protest bids). Both statistical models tend to underestimate WTP as compared to the observed (survey) values. However, we 311 consider that the predictive capacity of the models is acceptable (Table 6)

\begin{tabular}{ccccc}
\hline Mean WTP & \multicolumn{2}{c}{ WTP $>0$} & \multicolumn{2}{c}{ WTP $\geq 0$ without protest bids } \\
\cline { 2 - 5 } & OLS regression & Observed & Tobit model & Observed \\
& $€ 29.2$ & $€ 42$ & $€ 20.4$ & $€ 36.4$ \\
Scenario 1 & $€ 50.0$ & $€ 76$ & $€ 34.5$ & $€ 52$ \\
Scenario 2 & & & & \\
\hline
\end{tabular}

313 Table 6: Predicted WTP for Scenarios 1 and 2 with OLS and Tobit models.

314 Overall, the econometric analysis confirms the validity of responses, since WTP correlates as 315 expected with the main explanatory variables (see Table 7). WTP is positively correlated with 316 income with an elasticity of 0.35 in Scenario 1 and 0.54 in Scenario 2 (significant at the 99\% 317 level). WTP is also negatively correlated with age (99\% confidence level) and positively 318 correlated with membership in a nature-protection association.

\footnotetext{
${ }^{5}$ The estimated model is a semi-log model: $\log (\mathrm{WTP})=\mathrm{a}_{\mathrm{i}} \cdot \mathrm{X}_{\mathrm{i}}+\mathrm{b}_{\mathrm{i}} \log \left(\mathrm{Y}_{\mathrm{i}}\right)+\mathrm{C}$ where $\mathrm{Y}_{\mathrm{i}}$ are AGEZ, NUMBER OF CHILDREN and INCOME and $\mathrm{X}_{\mathrm{i}}$ are all other dependent variables except income. All parameters $b_{i}$ can directly be interpreted as elasticity.
} 
319 WTP seems to be strongly determined by the motivations quoted by respondents when 320 justifying their decisions to pay. Two binary variables were constructed to describe these 321 motivations. The first one takes the value 1 if respondent has quoted some reasons which are 322 related to use values (USE_VALUE) and the second one if respondent has quoted reasons 323 related to non-use values (NON_USE_VALUE). The estimated coefficients however show 324 that the effect of the first variable is much greater than the second (approximately 4 times) 325 and this holds for both scenarios. This means that individuals whose WTP is motivated by 326 direct use benefits are likely to pay $€ 17.3$ more than others. By contrast, quoting a non-use 327 benefit as WTP motivation only increases WTP by $€ 1.3$.

328 Another interesting result of the econometric analysis is that there is no statistical difference 329 between the "willingness to pay" amounts declared by households living above the aquifer 330 (and using it for their water supply) and others living outside the aquifer. The later may not be 331 aware of the boundaries of the aquifer, or wrongly believe their water supply currently 332 depends from the aquifer. They may also consider that they will be able to use that resource in 333 the new future if pipelines are constructed to import that water to where they live. This 334 finding suggests that users and non-users are equally concerned by groundwater protection. 


\begin{tabular}{|c|c|c|c|c|}
\hline Variable & Description & Coeff. & $\mathbf{T}$ & $\operatorname{Sig}^{(*)}$ \\
\hline LEISURE_WATER & $\begin{array}{l}\text { Indicator of the number } \& \text { frequency of water- } \\
\text { related leisure activities practiced }\end{array}$ & -0.015 & -0.51 & ns \\
\hline WELL & Respondent has a private well & 0.074 & 0.41 & ns \\
\hline NO_DRINK_TAP & Respondent never drinks tap water & 0.260 & 1.09 & ns \\
\hline POLLUTION_EXP & $\begin{array}{l}\text { Respondent had experience of tap water } \\
\text { interruption due to a pollution problem }\end{array}$ & 0.173 & 0.94 & ns \\
\hline KNOW_BILL & Respondent knows the amount of his water bill & -0.204 & -1.45 & ns \\
\hline $\begin{array}{l}\text { OTHER_ENV_PRO } \\
\text { B }\end{array}$ & $\begin{array}{l}\text { Sum of environmental problems that are } \\
\text { definitely more important than groundwater } \\
\text { pollution for the respondent }\end{array}$ & 0.031 & 0.58 & ns \\
\hline INDUSTRY_POL & $\begin{array}{l}\text { Respondent considers industries are major } \\
\text { sources of pollution for Alsatian groundwater }\end{array}$ & -0.095 & -0.73 & ns \\
\hline POL_SUBST & $\begin{array}{l}\text { Number of groundwater contaminants quoted by } \\
\text { the respondent (in a list) }\end{array}$ & 0.107 & 2.35 & $* *$ \\
\hline CREDIBLE_REF & $\begin{array}{l}\text { Respondent considers the description of the } \\
\text { current situation quite or very realistic/credible }\end{array}$ & 0.303 & 0.96 & ns \\
\hline $\begin{array}{l}\text { CREDIBLE_SCENA } \\
\text { RIO }\end{array}$ & $\begin{array}{l}\text { Respondent believes it is possible to restore } \\
\text { drinking water quality in the aquifer (Scenario 1) }\end{array}$ & 0.067 & 0.38 & ns \\
\hline USE_VALUE & $\begin{array}{l}\text { Respondent is willing to pay for reasons revealing } \\
\text { a use value }\end{array}$ & 2.850 & 14.16 & $* * *$ \\
\hline NON_USE_VALUE & $\begin{array}{l}\text { Respondent is willing to pay, for reasons } \\
\text { revealing non-use value }\end{array}$ & 0.322 & 2.18 & *** \\
\hline LOG_AGE & Logarithm of age & -0.071 & -0.33 & ns \\
\hline LOG_CHILDREN & Logarithm of number of children in the household & 0.069 & 0.40 & ns \\
\hline LOG_INCOME & Logarithm of income & 0.345 & 3.67 & $* * *$ \\
\hline WTP_DIFFICULT & $\begin{array}{l}\text { Respondent found it difficult to answer the WTP } \\
\text { question }\end{array}$ & -0.171 & -1.15 & ns \\
\hline INFO_INSUF & $\begin{array}{l}\text { The information provided was not considered } \\
\text { sufficient to answer the WTP questions }\end{array}$ & -0.135 & -0.90 & ns \\
\hline ENV_NGO & $\begin{array}{l}\text { Respondent is a member of an environmental } \\
\text { association }\end{array}$ & 0.582 & 3.09 & $* * *$ \\
\hline INTERCEPT & & -2.69 & -2.45 & ns \\
\hline $\mathrm{N}=342$ & LR $\operatorname{chi} 2(19)=393$ & .0000 & Pseudo & $=0.23$ \\
\hline
\end{tabular}

338 (*) : Sig stands for statistical significance. "ns" indicate that the variable is not significant; ** and *** indicate

339 the variable is significant at the $95 \%$ and $99 \%$ level. All variables included in the model improve the overall fit.

340 Others have been removed.

341 Table 7: Estimated Tobit model for $\log ($ WTP $)$ in Scenario 1.

\section{3.4. WTP aggregation and cost benefit analysis}

344 The main objective of the contingent valuation survey was to assess the benefits of two

345 scenarios for groundwater pollution remediation. The total benefits of each scenario can be

346 roughly estimated by extrapolating the average stated WTP to the entire population affected

347 by groundwater quality. The extrapolation can be done by simply multiplying the average

348 WTP by the number of households in the region and by ten years (period during which 
respondents have agreed to pay). The aggregation procedure is more complex if the survey

350 sample is not representative of the regional population. As this was the case in the present survey, the bias was corrected before extrapolating the results ${ }^{6}$. The aggregate willingness to pay for the entire region (considered as a proxy for groundwater protection benefits) was subsequently estimated at $€ 236$ million over a ten-year period for Scenario 1 (drinking-water 354 quality level) and $€ 377$ million for Scenario 2 (natural-groundwater quality level). Table 4 355 shows that the net present value for the two groundwater restoration scenarios is largely 356 positive (resp. € 224 and 340 million). From a pure welfare economics perspective, the results 357 suggest that the second scenario should be preferred. This conclusion should however be 358 considered with caution, considering uncertainties related to the population concerned (benefit 359 extrapolation) and the cost estimation (assumptions related to measure adoption rates, see 360 appendix).

\section{DISCUSSION}

363 The main objective of the case study presented in this paper was to investigate the relevance 364 of cost benefit analysis for assessing groundwater remediation, considering two scenarios 365 targeting different water quality objectives. It highlights a number of methodological 366 difficulties related to costs and to benefit-estimation procedures which are discussed in this 367 section.

\subsection{Cost estimate uncertainty}

370 Concerning costs, one of the main challenges lies in the scale at which WFD remediation

\footnotetext{
${ }^{6}$ The sample bias was corrected as follows. We calculated an average WTP per professional category in our sample, using the national occupational classification system. The adjusted values were then used to extrapolate results of the survey to the entire regional population.
} 
programmes have to be defined. While engineers are used to designing decontamination

372 programmes at scales ranging from a few hectares to few square kilometres, it is much more

373 difficult to assess the level of effort - both in technical and financial terms - required to

374 improve the quality of an aquifer extending over several thousand square kilometres, 375 particularly in the case of non-agricultural pollution. The case study presented in this paper 376 illustrates the complexity associated with the identification of multiple potential pollution 377 sources and the definition of technical measures that should be implemented to prevent any 378 further emission, or to contain and/or decontaminate existing pockets of contaminated 379 groundwater. The approach proposed in this paper, which consists of combining various 380 sources of statistical data with expert advice, allows a gross estimate of the total cost to be 381 produced. However, a high uncertainty is attached to the results obtained. This uncertainty 382 could probably not be reduced without engaging over costly surveys and studies to 383 characterise the actual pollution level in thousands of potentially contaminated or 384 contaminating sites and firms. If we accept that the uncertainty of the cost estimate is 385 irreducible, then the value to decision makers of the numerical results of CBA remains 386 limited, whatever efforts are made to assess the benefits. We contend however that the 387 economic approach provides a useful analytical framework for putting together pieces of 388 knowledge which are scattered among a large number of experts and stakeholders. In that 389 sense, the main outcome of an economic evaluation of costs and benefits is not the precise 390 figures that are produced, but the fact that it helped to construct a shared knowledge base on 391 which decision makers may rely when making and justifying their decisions.

\subsection{The limits of CVM for assessing the benefits of groundwater protection}

394 The paper also addresses several questions related to the use of contingent valuation for 395 assessing the benefits of groundwater protection in the European context. One of the main 
challenges is related to the nature of the benefits to be estimated. While most previous $\mathrm{CV}$

397 studies focussed on areas where groundwater was intensively used, the WFD requires

398 Member States to assess the benefits of groundwater protection for all types of aquifers,

399 including those which are not exploited. Economists are therefore asked to assess non-use

400 benefits, including the indirect benefits of groundwater remediation for dependent ecosystems

401 such as rivers and wetlands, and option and bequest values. One of the main problems is then

402 to accurately describe this indirect effect in CV surveys. This is all the more difficult that water scientists themselves are not able to model the complex relationships that determine pollution transfer from aquifers to rivers and wetlands, and the subsequent impacts on flora and fauna. If the information presented in the questionnaire is too vague, what does WTP

406 actually measure? In the present case, the difference between stated WTP for Scenarios 1 and 2 actually measure relatively "fuzzy" benefits (Lienhoop et Messner, 2009) and there are few options for reducing this fuzziness.

Another key difficulty related to the use of $\mathrm{CV}$ for evaluating groundwater protection benefits

410 is that respondents generally know very little about groundwater, how the resource works, the

411 threats that endanger it, and the benefits associated with its protection or remediation. This is 412 again more pronounced in the EU situation where only a few households rely solely on 413 private wells for their drinking-water supply. Let us recall that, in our case study, $82 \%$ of the 414 respondents considered that they were not well informed about the groundwater problem 415 described in the questionnaire, although more than half had already heard about groundwater 416 pollution, with $20 \%$ being able to quote a precise example. To make sure that all respondents 417 value the same good, questionnaires should therefore be designed to convey adequate 418 information on groundwater, its problems, and the benefits associated with its protection. As 419 already mentioned in the literature, this may have a WTP-enhancing effect. Another concern 
420 is that households may be in a situation of preference construction ${ }^{7}$ when stating their WTP,

421 which cast doubts on the validity of the values elicited (Slovic, 1995).

422 We also found, during the pre-test of the questionnaire, several poeple refusing to pay 423 (protesters) because they did not believe it would be technically feasible to restore 424 groundwater quality when pollution sources were so many and spread over so large an area. 425 To strengthen the credibility of our scenario, and to reduce the rate of protest bids, we had to 426 provide some technical description of the actions that would actually be undertaken to reach 427 the environmental objectives. Although we tried to minimise this information and to 428 emphasise the benefits that would be derived from the scenario, there is a risk that some of the 429 respondents may have evaluated their WTP with reference to what they thought the cost 430 would be, instead of truly evaluating scenarios in terms of increased utility. We believe this 431 risk is inherent to groundwater valuation: since respondents are not aware of how an aquifer 432 functions, they need to receive information not only on the resource and the services it 433 provides, but also on the technical actions that will be implemented to improve its quality.

\subsection{From WTP to aggregated benefits}

436 Once WTP has been estimated, another challenge of CBA lies in aggregating WTP at the 437 regional level. This involves identifying the population affected by the protection of the 438 specific aquifer under study. One approach suggested by Bateman consists of using distance 439 decay functions, which are estimated econometrically by adding distance as one explanatory 440 variable in the econometric model (Bateman, Day, Georgiou \& Lake, 2006). While this 441 approach is appealing for surface waters, which are often used for recreational purposes, it is 442 not clear whether it applies to groundwater or not. In the case study presented in this paper,

\footnotetext{
${ }^{7}$ Economists generally assume that $\mathrm{CV}$ survey respondents have pre-existing preferences for the environmental good under study, based on the level of satisfaction or utility it provides. Some authors however argue that people's preferences are sometimes constructed in the process of elicitation. This might be the case when respondents are not familiar with the good they are requested to value, groundwater in particular.
} 
443 for instance, we did not find any significant difference in WTP between respondents located 444 above the aquifer and others. This result is consistent with the observation that most 445 respondents justify their WTP decision by a concern for future generations. The question then 446 becomes how to identify the population that may be affected by the protection of the aquifer? 447 The problem was easily solved in our case study owing to the very specific geographical 448 configuration in which the aquifer occupies more than half of the region's area and is 449 surrounded by mountains that also delineate the region's boundaries ${ }^{8}$. Assuming that the 450 entire regional population is concerned was a reasonable assumption. But what should be 451 done in other contexts where the boundaries of the aquifer do not correspond to any relevant 452 territory from a political, cultural or economic perspective? Again, improving the accuracy of 453 WTP estimates is of limited use if their aggregation remains highly uncertain.

454 Another caveat of cost-benefit analysis that should be acknowledged is that, when dealing with groundwater-management issues, we generally do not properly consider time effects.

456 Even where hydrodynamic groundwater models are available, there is often great uncertainty 457 concerning the time-lag between the moment when remediation measures are implemented 458 (and costs paid) and the date at which benefits will fully appear. Even with a low discount rate 459 (typically 2 to $4 \%$ for groundwater, depending on the country), an error of 5 to 10 years can 460 totally change the results of the analysis.

\subsection{Conclusion}

462 A major innovation of the European Water Framework Directive (2000/60/EC) (WFD) is to 463 explicitly recognise that economics should play a key role in the development of river basin 464 management plan. Although Cost Benefit Analysis is not mentioned in the Directive, some

\footnotetext{
${ }^{8}$ We assume that the German population living on the other side of the Rhine (state of Baden Württemberg) does not feel concerned by groundwater protection on the French part of the alluvial valley. Indeed, hydrogeologists tell us that pollution occurring in one country will generally not impact the other one, the Rhine river acting as a hydraulic barrier (a few exceptions reporter though). Whether German citizen perceive things like this should however be checked though a specific survey.
} 
experts are suggesting using it to support the definition of water quality objectives (Brouwer, 466 2008). They suggest that CBA could be used to justify derogation under article 4 if it can be 467 proven that the costs of implementing the WFD outweigh the benefits of reaching good ecological status. By extension, the same argue that CBA could be used to set groundwater 469 quality objectives, under the general rules set by the Groundwater Directive (2006/118/EC).

470 For all the reasons advocated in the discussion above, and based on the case study presented 471 in this paper, we argue here that the use of CBA is inappropriate to justify derogations as part 472 of the Water Framework Directive under present conditions. Additional research needs to be conducted to ensure that non-use benefits can actually be captured by stated preference 474 methodologies when considering large-scale aquifers in the European context. Also, given 475 that primary studies are not feasible in each specific case study, significant efforts must be 476 devoted to the production of a set of CV studies representative of European groundwater situations. These studies should be produced with a uniform methodology, in order to 478 facilitate benefit transfers in the longer term. Additional research is also needed on the 479 engineering side of the analysis.

480 CBA nonetheless provides a very relevant framework for incorporating in a single coherent 481 picture complex environmental, engineering and economic information related to 482 groundwater contamination, pollution sources, measures that need to be implemented and 483 economic consequences. Many CBA analysts agree that, while this evaluation technique helps 484 organizing and structuring the arguments that support social decision making processes, it 485 does not replace them (see case studies reported in Brouwer \& Pearce, 2005). It also helps 486 confronting and integrating the visions of the different parties concerned. And it can be used 487 as a tool for communicating the rationale behind decisions to various stakeholders. Provided 488 that values used are scientifically sound. 
Acknowledgements: The research presented in this paper was part of the EU funded project

491 Background cRiteria for the IDentification of Groundwater thresholds (BRIDGE), Contract $\mathrm{n}^{\circ}$ 492 SSPI-2004-006538. We would like to thank Alain Saada (Brgm) for identifying and 493 characterising groundwater remediation measures. Roy Brouwer and Sebastiaan Hess (IVM, 494 Free University of Amsterdam) for the support they provided in drafting and testing the contingent valuation questionnaire. We also acknowledge the contribution from Hélène 496 Bouscasse and Mathieu Rouzère (students) and the technical support provided by Agence de

l’Eau Rhin Meuse (Sophie Nicolaï and Jean-Luc Salleron).

\section{REFERENCES}

Abdalla, C. W., 1994 - Groundwater values from avoidance cost studies : implication for policy and future research, American Journal of Agricultural Economics, 76, pp.

Bateman, I. J., Day, B. H., Georgiou, S. and Lake, I., 2006 - The aggregation of environmental benefit values: Welfare measures, distance decay and total WTP, Ecological Economics, 60, pp. 450-460Bergstrom, J.C., Boyle, K.J., Job, C.A., Jo Kealy, M., 1996. Assessing the economic benefits of ground water for environmental policy decisions. Journal of the American Water Resources Association 32, 279-291.

Brouwer, R (2008) The potential role of stated preference methods in the Water Framework Directive to assess disproportionate costs. Journal of Environmental Planning and Management, 51(5): 597-614

Brouwer, R. and Pearce, D. (2005). Cost benefit analysis and water resources management. Cheltenham / Northampton, Edward Elgar Publishing.

510 Carson, R.T., Flores, N.E., Meade, N.F., 2001. Contingent Valuation: Controversies and 511 Evidence, Environmental and Resource Economics 19, 173-210.

512 Edwards, S. F., 1988 - Option prices for groundwater protection, Journal of Environmental 513 Economics and Management, 15, pp. 475-487

514 Hardisty, P. E. and Özdemiroglu, E., 2005 - The economics of groundwater remediation and 515 protection, CRC Press, p. Jordan, J. L. and Elnagheeb, A. H., 1993 - Willingness to pay for improvements in drinking water quality, Water Resour. Res., 29, pp. 237-245

518 Kiel, K. and Zabel, J., 2001 - Estimating the Economic Benefits of Cleaning up Superfund 519 Sites : the case of Woburn, Massachussetts, Journal of Real Estate Finance and Economics 22, 520 pp. 163 à 184

521 Lazo, J. K., Schulze, W. D., McClelland, G. H. and Doyle, J. K., 1992 - Can Contingent 
Valuation Measure Nonuse Values?, American Journal of Agricultural Economics, 74, December 1, 1992, pp. 1126-1132

Lienhoop, N. and Messner, F., 2009 - The Economic Value of Allocating Water to PostMining Lakes in East Germany, Water Resources Management, 23, 2009/03/01, pp. 965-980

Pearce, D., 1998 - Environmental Appraisal and Environmental Policy in the European Union, Environmental and Resource Economics, 11, 1998/04//, pp. 489-501

Poe, G. L., Boyle, K. J. and Bergstrom, J. C. (2001). A preliminary analysis of contingent values for ground water quality revisited. The Economic Value of Water Quality. J. C. Bergstrom, K. J. Boyle and G. L. Poe. Cheltenham, U.K., Edward Elgar: 137-162.

Press and Söderqvist, T. (1998). On estimating the benefits of groundwater protection : a contingent valuation study in Milan. Regulating chemical accumulation in the environment: the integration of toxicology and economics in environmental policy making. T. Swanson and M. Vighi. Cambridge, Cambridge University Press: 278.

Quevauviler, P., 2008 - From the 1996 groundwater action programme to the 2006 groundwater directive - what have we done, what have we learnt, what is the way ahead ?, Journal of Environmental Monitoring, 10, pp. 408-421

Randal, A., Dezoysa, D. and Yu, S. (2001). Groundwater, surface water and wetland vakuation in Ohio. The economic value of water quality. J. C. Bergstrom, K. J. Boyle and P. G. L. Cheltenham UK, Edward Elgar: 83-99.

Rinaudo, J.-D. and Loubier, S. (2005). Cost-benefit analysis of large scale groundwater remediation in France. Cost Benefit Analaysis and Water Resources Management. R. Brouwer and D. Pearce. Cheltenham /Northampton, Edward Elgar Publisher: 290-314

Ryan, M., Scott, D.A., Donaldson, C., 2004. Valuing health care using willingness to pay: a comparison of the payment card and dichotomous choice methods. Journal of Health Economics 23, 237-258.

547 Rozan, A., Stengter, A. and Willinger, M., 1997 - Valeur de préservation de la qualité de l'eau souterraine : une comparaison entre usagers et non-usagers, Cahiers d'Economie et Sociologie Rurales, 45, pp. 62-92

SharefkinN, M., Shechter, M. and Kneese, A., 1984 - Impacts, costs, and techniques for mitigation of contaminated groundwater: A review, Water Resour. Res., 20, pp. 1771-1783

Slovic, P., 1995 - The construction of preference American Psychologist, 50, pp. 364-371.

553

554

Stenger, A. and Willinger, M., 1998 - Preservation value for groundwater quality in a large aquifer: a contingent valuation study of the Asatian aquifer, Journal of Environmental Management, 53, pp. 177 - 193

Tentes, G. and Damigos, D., 2012 - The Lost Value of Groundwater: The Case of Asopos River Basin in Central Greece, Water Resources Management, 26, pp. 147-164

Yadav, S. N. and Wall, D. B., 1998 - Benefit-cost analysis of best management practices implemented to control nitrate contamination of groundwater, Water Resour. Res., 34, pp. 497-504 


\section{A.1. DEFINITION OF MEASURE AND UNIT COST ESTIMATE}

567

Two types of measures can be applied to the different pollution sources. Preventive measures aim at reducing new contamination of the aquifer whereas remediation measures aim at removing existing stocks of COV present in soils or groundwater.

\section{$\underline{\text { A.1.1. Remediation measures }}$}

Remediation measures can apply to large scale industrial sites (abandoned sites or sites in activity) as well as to small sites (car repair workshops for instance). Concerning historical

573 abandoned sites, they consist in (i) conducting risk assessment studies in $100 \%$ of the sites, (ii) implementing soil and water sampling, analysis and surveillance (installation of monitoring wells in $50 \%$ of the sites) and decontaminating groundwater pollution plumes or contaminated soils located above the aquifer (approximately $20 \%$ of the sites are concerned). The type of measure to be implemented in each site was selected considering the extent of soil and water contamination (described in the BASIAS database). The cost was estimated for each site through an extrapolation of real cost data obtained from a limited number of sites in the case study area.

We also consider that small scale soil and water contamination occurs in firms in activity but no detailed database allows locating where exactly this happens. The probability of soil and

583 water contamination varies depending on the economic activity. To assess the cost of the 584 programme of measure, we assume, for each branch of activity, the percentage of firms where: (i) a risk assessment study has to be implemented (cost of about €5000), (ii) investigative and surveillance soil and water monitoring has to be implemented (cost ranging 
from $€ 10000$ to 16000 ) or (iii) remediation measures actually have to be implemented (cost

588 from $€ 8000$ for small firms to $€ 500000$ for large ones).

589

590

591

592

593

594

595

596

597

598

599

600

601

602

603

604

605

606

607

608

609

\section{A.1.2. Preventive measures}

Preventive measures which can be implemented to reduce recurring or accidental soil and groundwater contamination may be grouped into the following five categories:

Measures aimed at reducing accidental leakage by constructing watertight areas under storage tanks, removing all underground pipes and tanks, securing all areas where solvents are transported or manipulated, constructing retentions to recover solvents in case of accident, etc. The average estimated cost of this type of measure ranges from $€ 1,000$ for very small firms to $€ 10,000$ for larger industrial sites.

- Measures aimed at collecting all used solvents and other wastes containing solvents: this implies constructing storage premises for used solvents (which are sometimes still discharged directly into sewage systems or into the environment) and organising their collection by firms specialised in the treatment and recycling of toxic wastes. The cost of this type of measure depends on the volume of solvents to be collected and treated ( $€ 1 /$ litre of solvent). The volume is estimated for each industrial branch, based on expert judgement.

- Clean technologies for reducing emissions of VOC: these include the use of technologies where VOC are recycled (printing industry, painting-related activities, mechanical industries, etc.) Cost of equipment (investment) varies significantly from one industry to another. Average values were estimated based on various examples found in the literature or identified by experts. Estimated investment costs range between $€ 2,000$ and $€ 200,000$. Operational and maintenance costs are assumed to be 
relatively unchanged (in many cases, they may even be reduced by the change in technology).

- Substitution of chlorinated solvents by other solvents and/or use of technologies which do not require CS. For instance, cleaning of equipment used for painting can be done with ultrasonic devices; metal cleaning before coating can be done using bacteriological processes instead of solvents; and so on. Estimated investment costs range from $€ 10,000$ to $€ 200,000$ depending on the branch of activity and the size of the company.

- Wastewater treatment using activated coal filters in a stripping tower (where solvents evaporate) with an activated coal filter to remove solvents from the vapours. The costs considered are investment and operational costs. To assess operational costs, we assume a concentration of solvents and a total volume to be treated; we then calculate the quantity of activated granulated coal needed to treat the wastewater and the related cost. Wastewater treatment is considered only for the textile industry, coffee processing, and essential oil extraction. zones and conducting surveillance chemical analyses to detect any traces of pollution before it can generate a plume in groundwater. Investment costs are assessed as follows. For large industrial sites, we assume that a Simplified Risk Assessment Study is carried out and two monitoring wells are drilled for a total cost of $€ 25,000$. An additional $€ 1,500$ are estimated for recurring operational costs. For medium-size sites, one SRA study is carried out and one well drilled $(€ 15,000)$ whereas small sites have to conduct an SRA study only $(€ 5,000)$. 


\section{A.2. COST ESTIMATION}

635 One-off investment and yearly operational costs are estimated separately for each type of

636 measure separately.

637 Investment costs are assessed as follows:

$638 \quad C_{m}=\sum_{i}\left(\alpha_{t, m}^{i}-\alpha_{c, m}^{i}\right) \cdot N^{i} \cdot c_{m}^{i}$

639 Where:

$640 \quad \mathrm{C}_{\mathrm{m}}$ is the total cost of the measure " $\mathrm{m}$ ",

$641 \quad \alpha_{t, m}^{i}$ is the targeted rate of adoption of measure " $m$ " for industries of branch " $\mathrm{i}$ ",

$642 \quad \alpha_{c, m}^{i}$ is the current rate of adoption of measure " $m$ " for industries of branch " $\mathrm{i}$ ",

$643 \quad \mathrm{~N}^{\mathrm{i}}$ is the number of industries of branch " $\mathrm{i}$ " which are involved in measure " $\mathrm{m}$ ",

$644 \quad c_{m}^{i}$ is the average unit cost of implementing measure " $m$ " for one company of branch

$645 \quad$ “i”.

646 In practice, each branch " $i$ " is further split into several categories depending on the size

647 (number of employees), and parameters such as unit costs $c^{i}$ and percentage of adoption

648 (current and targeted) are estimated for each size. The same type of calculation is carried out

649 for recurring costs (operational and maintenance). The values for all parameters $\left(\alpha_{t, m}^{\mathrm{i}}, \alpha_{\mathrm{c}, \mathrm{m}}^{\mathrm{i}}\right.$,

$650 \quad \mathrm{~N}^{\mathrm{i}}, \mathrm{c}_{\mathrm{m}}^{\mathrm{i}}$ ) were estimated based on extensive expert consultation, which was conducted with

651 significant support from the Rhin Meuse Water Agency.

652 Recurring operational costs are assessed in the same way. Investment and operational costs

653 are then aggregated assuming a $4 \%$ discount rate and ten years duration for the programme of

654 measures (this assumption is also used when assessing the benefits in the CV survey).

655 The tool can be used to assess the cost of achieving various groundwater quality objectives. 